MANUSKRIP PENELITIAN

\title{
ANALISIS KEJADIAN KOMPLIKASI AKUT DAN KRONIS PADA PASIEN DIABETES MELITUS TIPE-2
}

\author{
Hendro Djoko Tjahjono
}

Email: hendrodjokotjahjono@yahoo.co.id

\begin{abstract}
ABSTRAK
Diabetes melitus merupakan sindrom gangguan metabolisme karbohidrat, lemak dan protein yang disebabkan oleh kurangnya sekresi insulin atau penurunan sensitifitas jaringan terhadap insulin yang bersifat kronis. Pasien diabetes melitus yang tidak melakukan pengobatan dan perawatan dengan baik, dapat mengakibatkan terjadinya komplikasi. Penelitian ini bertujuan untuk menganalisis terjadinya komplikasi akut dan kronis pada pasien diabetes melitus di di poliklinik metabolik endokrin RSUPN Cipto Mangunkusumo. Hasil menunjukkan dari 16 pasien diabetes melitus yang berpatisipasi dalam penelitian ini, didapatkan bahwa mengalami komplikasi akut diantaranya 4 responden $(25 \%)$ dan komplikasi kronis yaitu 4 responden $(25 \%)$ dan yang mengalami komplikasi akut serta kronis sebanyak 8 orang (50\%). Dengan demikian, untuk mencegah terjadinya komplikasi lanjutan maka diperlukan identifikasi dan deteksi dini dengan melakukan tindakan-tindakan preventif kepada pasien diabetes melitus sehingga kejadian komplikasi dapat diminimalisasi.
\end{abstract}

Kata kunci: Diabetes melitus, Komplikasi

\begin{abstract}
Diabetes mellitus is a syndrome of disorders of carbohydrate, fat and protein metabolism which caused by a lack of insulin secretion or a decrease in chronic tissue sensitivity to insulin. Diabetes mellitus patients who do not take properly care and medication, can lead to complications. This study aims to analyze the occurrence of acute and chronic complications in patients with diabetes mellitus in metabolic endocrine policlinic of RSUPN Cipto Mangunkusumo hospital. The results showed that of 16 diabetes mellitus patients who participated in this study, it was found that experiencing acute complications including 4 respondent $(25 \%)$ suffering, chronic complications are 4 respondent $(25 \%)$, and also the respondent which get both of the complications are 8 respondent $(50 \%)$. Thus, to prevent further complications, identification and early detection are required by taking preventive measures for diabetic mellitus patients, so that the incidence of complications can be minimized.
\end{abstract}

Keywords: Diabetes mellitus, Complications 


\section{Pendahuluan}

Diabetes melitus (DM) merupakan suatu sindrom gangguan metabolisme karbohidrat, lemak dan protein yang disebabkan oleh kurangnya sekresi insulin atau penurunan sensitifitas jaringan terhadap insulin yang bersifat kronis yang ditandai dengan peningkatan konsentrasi glukosa darah (Guyton, 2007; Bilous \& Donelly, 2014).

Prevalensi diabetes terkait usia meningkat dari 5,9\% sampai $7,1 \%$, berkisar antara 246-380 juta jiwa, diseluruh dunia pada kelompok usia 20-79 tahun yang kejadiannya diperkirakan meningkat 55\%. International Diabetes Federation (IDF) memperkirakan terdapat 382 juta orang yang hidup dengan diabetes di dunia pada tahun 2013. Pada tahun 2035 jumlah tersebut diprediksi akan meningkat menjadi 592 juta orang. Selama dekade terakhir, prevalensi diabetes telah meningkat lebih cepat di negara-negara berpenghasilan rendah dan menengah daripada di negara-negara berpenghasilan tinggi (International Diabetes Federation, 2009 ; Kemenkes, 2014).

Berdasarkan data Riskesdas 2007, prevalensi nasional DM di Indonesia untuk usia di atas 15 tahun sebesar $5,7 \%$ (1,5\% pasien diabetes yang sudah terdiagnosis sebelumnya dan 4,2\% Pasien baru terdiagnosis DM). Menurut IDF (2014), saat ini diperkirakan 9,1 juta orang penduduk di diagnosis DM dengan prevalensi terbanyak wanita Pasien diabetes adalah mereka yang berusia antara 50-54 tahun sebesar 13,54\% sedangkan pada kelompok pria adalah mereka yang berusia 60-64 tahun sebesar 13,46\% (Suyono, 2015 ; Rudijanto et al, 2015).

Pasien diabetes dapat mengalami komplikasi akut seperti koma hipoglikemia, hiperglikemia ketoasidosis atau non ketoasidosis, efek Somogyi, dan dawn phenomenon. Selain itu, jika tidak dikelola dengan baik maka DM dapat mengakibatkan terjadinya berbagai penyulit menahun seperti mikroangiopati dan makroangiopati yang menyebabkan penyakit serebrovaskular, penyakit jantung koroner, penyakit pembuluh darah tungkai, penyulit pada mata, ginjal dan syaraf, rentan terhadap infeksi.

Pasien DM mempunyai resiko mengalami penyakit jantung dan pembuluh darah otak 2 kali lebih besar, 5 kali lebih mudah menderita ulkus/gangrene, 7 kali lebih mudah mengidap gagal ginjal terminal dan 25 kali lebih mudah mengalami kebutaan akibat kerusakan retina daripada pasien non DM. Penyakit mikrovaskuler terbukti kuat berhubungan dengan durasi dan keparahan hiperglikemia. Seiring lamanya diabetes yang diderita pasien, prevalensi retinopati, nefropati dan neuropati lebih tinggi pada Pasien diabetes dengan kontrol glikemik yang buruk (Scobie, 2007 ; Bilous, 2014 ; Boedisantoso, 2018 ; Waspadji, 2018).

Pelayanan kesehatan yang kurang baik serta rendahnya proporsi kasus yang ditangani dapat berkontribusi pada peningkatan insiden diabetes dan komplikasi CHF. Disisi lain rendahnya kesadaran dan ketidaktahuan Pasien diabetes tentang pentingnya pengelolaan penyakit seperti menjalani aktifitas fisik secara teratur, disiplin dalam mengatur nutrisi, mempertahankan berat badan ideal, melakukan kontrol dan rutin minum dapat memperburuk kondisi penyakitnya (Darmayanti, 2008)

Prevalensi ketidakpatuhan pasien DM terhadap pengobatan dan perawatan di beberapa negara di dunia dilaporkan cukup tinggi. Di India, $43 \%$ pasien tidak patuh pada program diit dan monitoring glukosa, $48 \%$ pasien DM tidak mengikuti program aktifitas fisik di Amerika. Studi di California Utara, menemukan 25\% pasien DM tipe 2 menunjukkan ketidakpatuhan terhadap penggunaan $\mathrm{OHO}$ dan $85 \%$ tidak membeli obat yang diresepkan (Delameter, 2006). Sedangkan menurut Rasdianah dkk (2016), 123 pasien DM tipe 2 di Yogjakarta memiliki tingkat kepatuhan yang rendah terhadap penatalaksanaan pengobatan DM. Data survey yang dilakukan oleh Fakultas Kesehatan Masyarakat Univesitas Indonesia, 80\% pasien DM menyuntik insulin tidak higienis, 58\% menyuntik insulin dengan dosis tidak sesuai, $77 \%$ memonitor dan menginterpretasikan hasil pemeriksan kadar gula darah secara keliru serta 75\% tidak makan sesuai anjuran (Darmayanti, 2008).

Dalam konferensi NANDA (North AmericanNursing Diagnosis Association, tahun 1992, masalah kepatuhan (adherence) merupakan diagnosa keperawatan yang harus ditangani secara spesifik oleh perawat. Perawat memiliki serangkaian intervensi untuk mencegah dan menangani masalah adherence. Intervensi keperawatan yang digunakan pada masalah adherence, antara lain melakukan pendidikan kesehatan, menetapkan tujuan bersama, menejemen nutrisi, membantu pasien melakukan modifikasi diri dan memfasilitasi tanggungjawab diri pasien. Perawat bersama pasien dapat mengenali berbagai faktor pendukung dan penghambat kepatuhan, mengenali harapan dan keinginan pasien dalam mematuhi anjuran kesehatan, serta mampu memotivasi pasien untuk patuh (Doenges, 2000, Dochterman \& Bulechek, 2004 dalam Purba 2008).

\section{Metode}

Metode yang digunakan adalah dengan pendekatan analistik observasional dan wawancara pada pasien diabetes melitus tipe-2. Instrument yang digunakan adalah format pengkajian pasien, data pemeriksaan laboratorium, lembar observasi dan data sekunder lain yang mendukung. 
Kriteria inklusi yang digunakan yaitu pasien diabetes melitus yang berusia $\geq 40$ tahun, bersedia ikut berpartisipasi dan pasien menderita (di diagnosa) diabetes minimal 5 tahun, sedangkan kriteria eksklusinya adalah pasien yang tidak kooperatif dan pasien yang tidak mampu menunjukkan kemampuannya dalam berbicara, mendengar maupun menulis.

Pengambilan data dilakukan secara crosssectional pada tanggal 4 Mei 2019 dan diperoleh responden sebanyak 16 orang.

\section{Hasil}

Data responden yang dikumpulkan meliputi data demografi (umur, HbA1C, IMT, lama menderita DM, komplikasi, riwayat merokok, riwayat mengkonsumsi alcohol, riwayat pengobatan). Adapun distribusi dari data demografi dari responden akan disajikan dalam bentuk tabel distribusi sebagai berikut :

Tabel 1 Distribusi data demografi responden DM di di poliklinik metabolik endokrin RSUPN Cipto Mangunkusumo ( $\mathrm{n}=16)$

\begin{tabular}{llcc}
\hline \multicolumn{2}{c}{ Demografi } & Frekwensi & Prosentase \\
\hline Umur & $\begin{array}{l}40-50 \\
\text { tahun } \\
51-60\end{array}$ & 7 & $44 \%$ \\
& $\begin{array}{l}\text { tahun } \\
\text { HbA1C }\end{array}$ & 9 & $56 \%$ \\
& $\begin{array}{l}5,6 \%-6,4 \% \\
\geq 6,5 \%\end{array}$ & 4 & $25 \%$ \\
\hline IMT & BB normal & 4 & $25 \%$ \\
& BB \\
& beresiko & 5 & $31,25 \%$ \\
& $\begin{array}{l}\text { Obesitas I } \\
\text { Obesitas II }\end{array}$ & 5 & $31,25 \%$ \\
& & 2 & $12,5 \%$ \\
\hline Lama & $1-5$ tahun & 3 & $19 \%$ \\
menderita & $6-10$ tahun & 7 & $44 \%$ \\
DM & $11-16$ & 5 & $31 \%$ \\
& $\begin{array}{l}\text { tahun } \\
\text { 16-20 }\end{array}$ & 1 & $6 \%$ \\
& tahun & & \\
\hline
\end{tabular}

\begin{tabular}{llcc}
\hline \multicolumn{2}{c}{ Demografi } & Frkwsi & Prosentase \\
\hline Komplikasi & Mikrovaskuler & 4 & $25 \%$ \\
& Makrovaskuler & 4 & $25 \%$ \\
& Keduanya & 8 & $50 \%$ \\
\hline Riwayat & Merokok & 5 & $31,25 \%$ \\
merokok & Alkohol & 1 & $6,25 \%$ \\
dan alkohol & Tidak & 10 & $62,5 \%$ \\
& keduanya & & \\
\hline Pengobatan & OHO & 9 & $73 \%$ \\
& Insulin & 3 & $12 \%$ \\
& Kombinasi & 4 & $15 \%$ \\
\hline
\end{tabular}

\section{Pembahasan}

Berdasarkan tabel 1 diatas, terlihat sebagian besar responden berusia 51-60 tahun yaitu 9 orang (56\%), nilai HbA1C >6,5\% sebanyak 12 orang (75\%), IMT terbanyak dimiliki responden dengan katagori BB beresiko dan Obesitas I yaitu 5 orang $(31,25 \%)$, lama menderita DM yang terbanyak 6-10 tahun sebanyak 7 orang $(44 \%)$, memiliki komplikasi mikrovaskuler dan makrovaskuler sebanyak 8 orang (50\%), tidak mempunyai riwayat merokok dan alkohol 10 orang $(62,5 \%)$, dan menjalani pengobatan $\mathrm{OHO} 9$ orang (73\%).

Pada kondisi hiperglikemi dapat melemahkan kapasitas sekresi insulin dan menambah berat resistensi insulin yang dapat mempengaruhi proses metabolik dalam tubuh (Suharmiati, 2003). Hiperglikemi bila berkepanjangan dan tidak dikontrol dengan baik menyebabkan komplikasi angiopati dan neuropati. Kedua hal ini yang menyebabkan gangguan sirkulasi darah yang akan menghambat suplai oksigen pada serabut saraf dan kerusakan endotel pembuluh darah, hal ini akan memicu tumbuhnya bakteri terutama bakteri anaerob sehingga pada akhirnya timbul luka kaki diabetik.

Berdasarkan indikator usia, pasien DM yang terbanyak berusia 51-60 tahun. Menurut laporan National Institutes of Health, NIH (2002), di Amerika Serikat kurang lebih 15 juta sampai 30 juta laki-laki mengalami/menderita diabetes melitus karena berbagai faktor. Sedangkan menurut National Diabetes Information Clearinghouse (NIDDK) (2008), diabetes melitus adalah masalah yang umum terjadi pada individu seiring bertambahnya usia.

Sedangkan pada indikator data demografi IMT yang terbanyak dialami oleh responden dengan katagori BB beresiko dan Obesitas I. Menurut Mota et al (2003), salahsatu faktor yang berhubungan dengan DM adalah obesitas.

DM terjadi karena beberapa faktor yaitu faktor genetik, obesitas, kurang gerak, faktor makanan, hingga dapat terjadi komplikasi terjadinya luka pada kaki. Pada penderita DM dapat pula terjadi gangguan berupa kerusakan sistem syaraf (neuropati) yang terbagi menjadi tiga kelompok (kerusakan sistem saraf perifer, kerusakan sistem saraf otonom, dan kerusakan sistem 
saraf motorik). Kerusakan sistem saraf perifer pada umumnya dapat menimbulkan gejala kesemutan, nyeri pada tangan dan kaki, serta berkurangnya sensitivitas atau mati rasa (intensitivity), dimana kondisi ini akan sangat berbahaya karena penderita tidak dapat merasakan apa-apa sekalipun kakinya terluka, yang pada akhirnya mengakibatkan penderita terlambat untuk menyadari bahwa kakinya sudah terluka.

Untuk katagori lama menderita DM, yang terbanyak responden menderita DM selama 6-10 tahun. Hal ini sejalan dengan penelitian ini yang menunjukkan adanya hubungan antara lama menderita DM dengan IMT dimana semakin berat seseorang akan meningkatkan resiko menderita DM dibandingkan pasien yang kurus atau memiliki IMT normal.

Selanjutnya pada katagori komplikasi DM dan riwayat pengobatan, diperoleh hasil bahwa responden yang mengalami komplikasi mikro-makrovaskuler lebih banyak dibandingkan dengan responden yang hanya mengalami komplikasi akut atau kronis saja (hanya sahsatu yg diderita). Menurut Mota et al (2003), petugas kesehatan perlu memperhatikan faktor-faktor resiko terjadinya DM seperti riwayat pengobatan dan factor pencetus munculnya komplikasi lebih dini, terutama komplikasi kronis. Dalam penelitian ini juga dikatakan bahwa terapi diabetes yang konsumsi oleh responden terdiri dari terapi tunggal (diit), maupun terapi kombinasi (diet dengan $\mathrm{OHO}$ atau insulin) serta obat-obat lain selain obat diabetes melitus.

\section{Kesimpulan}

Kesimpulan dari penelitian ini adalah dari 16 responden, 8 orang mengalami komplikasi akut dan kronis (gabungan keduanya), sedangkan sisanya komplikasi akut atau kronis yaitu 4 responden. Beberapa faktor yang dapat memengaruhi timbulnya komplikasi akut dan kronis antara lain usia, lama menderita, HbA1C, IMT, Lama menderita diabetes, riwayat merokok dan atau alkohol

\section{Referensi}

ADA, (2017), The Journal of Clinical and Applied Research and Education, Januari, Vol.40, Supplemen 1, Diabetes Care : Standards of Medical Care in Diabetes

Adhi, Bayu, TI, Rodiyatul F. S. dan Hermansyah, 2011. An Early Detection Method of Type-22 Diabetes Mellitus in Public Hospital. Vol.9, No.2, Telkomnika

Aini, N \& Aridiana, L.M., (2016) Asuhan Keperawatan pada Sistem Endokrin, dengan pendekatan NANDA NIC NOC, Salemba Medika, Jakarta
Bilous, R \& Donelly, R (2014). Buku Pegangan Diabetes, Edisi 4, Jakarta: Bumi Medika.

Giuliano F.A., Lerichie A, Jaudinot E, Gnedre A.S (2004), Prevalence of erectile dysfunction among 7689 patient with diabetes or hypertension or both, Adult Urology 64 (6) :1196-1201, Elsevier Inc.

Mota et al (2003), Erectile dysfunction in diabetes mellitus, Romanian journal of internal medicine. www.researchgate.net/publications/81933143; vol $41: 2$

National Diabetes Information Clearinghouse (NIDDK), (2008). Sexual and Urologic problem of Diabetes, NIH Publication No.09-5135.

Rudijanto et al (2015). Konsensus Pengelolaan dan Pencegahan Diabetes Melitus Tipe 2 Di Indonesia, PB Perkeni 